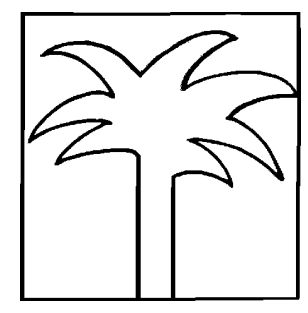

\title{
Lessons for development from Pacific island countries
}

\author{
Satish Chand
}

This paper argues that initial conditions, in terms of the set of institutions (put) in place at the birth of a nation, matter for future prosperity. Several propositions from the New Institutional Economics literature are corroborated by evidence from fourteen Pacific island countries that lead to recommend policy settings necessary for the economic development. These recommendations include the establishment of clear property rights with the absolute paramountcy of the rule of law, a simple regulatory system that is subject to minimal discretion, an active media, and an independent judiciary. On the last two, foreign participation is necessary given the small and enclave nature of these professions.
Satish Chand is a Fellow in the Asia Pacific School of Economics and Management and the Research School of Pacific and Asian Studies, The Australian National University.
If economic policymaking is about accelerating the pace of human development, then the fourteen islands nations of the South Pacific offer several lessons. These lessons are particularly important given the diversity in policy settings across these countries and yet their poor economic performance. These lessons are relevant to all developing countries, but perhaps most relevant to current Pacific island countries, given the rising incidences of poverty, crime, and political instability in the region. A word of caution is in order here. Getting the settings 'right' has the potential to deliver large and ongoing benefits, but mistakes could have catastrophic consequences for the welfare of current and future generations. Initial conditions matter for future prosperity and inertia that builds over time makes dismantling policies difficult.

The economics profession constantly debates the circumstances most conducive to growth in income of societies. Crosscountry experiences over the last sixty years, following World War II, have a lot of lessons to offer. But, given the extent of repetition of mistakes in policy formulation, one clear lesson from history is that we seldom, if ever, 


\begin{tabular}{|c|c|c|c|c|c|c|c|c|}
\hline & $\begin{array}{l}\text { Population } \\
\text { (‘000) }\end{array}$ & $\begin{array}{l}\text { Population } \\
\text { growth } \\
\text { (\% p.a) }\end{array}$ & $\begin{array}{c}\text { GDP } \\
\text { per capita } \\
\text { (US\$) }\end{array}$ & $\begin{array}{c}\text { GDP } \\
\text { growth } \\
(\% \text { per annum })\end{array}$ & $\begin{array}{c}\text { Adult } \\
\text { literacy } \\
\text { (per cent) }\end{array}$ & $\begin{array}{c}\text { Infant mortality } \\
\text { (per ‘000 } \\
\text { live births) }\end{array}$ & $\begin{array}{c}\text { Life } \\
\text { expectancy }\end{array}$ & $\begin{array}{c}\text { Aid per } \\
\text { capita } \\
\text { (current US\$) }^{a}\end{array}$ \\
\hline Cook Islands & 19 & 0.65 & 4521 & .. & $\begin{array}{c}100 \\
(1994-97)\end{array}$ & $\begin{array}{c}25 \\
(1998)\end{array}$ & $\begin{array}{c}69 \\
(1991-93)\end{array}$ & .. \\
\hline Fiji & 825 & 1.24 & 1,982 & $\begin{array}{c}-3.7 \\
(1998)\end{array}$ & $\begin{array}{c}92 \\
(1995)\end{array}$ & $\begin{array}{c}19 \\
(1998)\end{array}$ & $\begin{array}{c}72.7 \\
(1998)\end{array}$ & 46.1 \\
\hline Kiribati & 91 & 1.42 & 594 & $\begin{array}{c}6.1 \\
(1998)\end{array}$ & $\begin{array}{c}97 \\
(1999)\end{array}$ & $\begin{array}{c}58 \\
(1998)\end{array}$ & $\begin{array}{c}60.9 \\
(1998)\end{array}$ & 200.8 \\
\hline Marshall Islands & 62 & 3.21 & 1,509 & $\begin{array}{c}3.7 \\
(1995)\end{array}$ & $\begin{array}{c}91 \\
(1999)\end{array}$ & $\begin{array}{c}26 \\
(1998)\end{array}$ & $\begin{array}{c}62.8 \\
(1994-97)\end{array}$ & 811.3 \\
\hline Micronesia, Fed. States & 118 & 2.03 & 1,841 & $\begin{array}{c}0.3 \\
(1999)\end{array}$ & $\begin{array}{c}81 \\
(1999)\end{array}$ & $\begin{array}{c}28.5 \\
(1998)\end{array}$ & $\begin{array}{c}67.3 \\
(1998)\end{array}$ & 705.6 \\
\hline Nauru & 12 & 1.85 & 2,900 & .. & $\begin{array}{c}90 \\
(1999)\end{array}$ & $\begin{array}{c}26 \\
(1994-97)\end{array}$ & $\begin{array}{c}60.8 \\
\text { (2000 est.) }\end{array}$ & .. \\
\hline Niue & 2 & 0.90 & 2,250 & .. & $\begin{array}{c}99 \\
(1991-93)\end{array}$ & $\begin{array}{c}18 \\
(1994)\end{array}$ & $\begin{array}{c}66 \\
(1994-97)\end{array}$ & .. \\
\hline Palau & 19 & 2.41 & 6,448 & .. & $\begin{array}{c}98 \\
(1999)\end{array}$ & $\begin{array}{c}19 \\
(1995)\end{array}$ & $\begin{array}{c}71 \\
(1996)\end{array}$ & 4814.1 \\
\hline Papua New Guinea & 4807 & 2.22 & 756 & $\begin{array}{c}0.9 \\
(1999)\end{array}$ & $\begin{array}{c}72 \\
(1995)\end{array}$ & $\begin{array}{c}59.4 \\
(1998)\end{array}$ & $\begin{array}{c}58.2 \\
(1998)\end{array}$ & 78.5 \\
\hline Samoa & 169 & 1.43 & 1,255 & $\begin{array}{c}1.3 \\
(1998)\end{array}$ & $\begin{array}{c}98 \\
(1999)\end{array}$ & $\begin{array}{c}25 \\
(1998)\end{array}$ & $\begin{array}{c}68.7 \\
(1998)\end{array}$ & 215.3 \\
\hline Solomon Islands & 448 & 3.14 & 712 & $\begin{array}{c}4.0 \\
(1999)\end{array}$ & $\begin{array}{c}62 \\
(1999)\end{array}$ & $\begin{array}{c}22.2 \\
(1998)\end{array}$ & $\begin{array}{c}70.8 \\
(1998)\end{array}$ & 102.4 \\
\hline Tonga & 100 & 0.28 & 1,614 & $\begin{array}{c}2.2 \\
(1999)\end{array}$ & $\begin{array}{c}95.9 \\
(1991-93)\end{array}$ & $\begin{array}{c}21.3 \\
(1998)\end{array}$ & $\begin{array}{c}70.6 \\
(1998)\end{array}$ & 259.6 \\
\hline Tuvalu & 10 & 2.69 & 1,215 & .. & $\begin{array}{c}99.5 \\
(1991-93)\end{array}$ & $\begin{array}{c}29 \\
(1997)\end{array}$ & $\begin{array}{c}65.6 \\
(1991-93)\end{array}$ & .. \\
\hline Vanuatu & 200 & 2.41 & 1,276 & $\begin{array}{c}-2.0 \\
(1999)\end{array}$ & $\begin{array}{c}70 \\
(1989-90)\end{array}$ & $\begin{array}{c}35.5 \\
(1998)\end{array}$ & $\begin{array}{c}65 \\
(1998)\end{array}$ & 221.8 \\
\hline
\end{tabular}

Notes: The population figures are projections for mid 2000; population growth data is for 1999; GDP-per capita data is for 1998; the data on adult literacy rates are for the most recent year available as indicated in the parenthesis; ${ }^{a}$ data for 1998, the most recent available; and, ${ }^{\text {b }}$ data sourced

from http://www.oneworld.org/ni/issue253/facts.htm. Electronic databases of the following organisations were used to extract the above data: South Pacific Trade Directory, UNESCAP, UNESCO, UNICEF, WHO, World Bank. 
learn from it. The Pacific island country experience strongly supports this proposition-the Pacific island countries have considerable diversity on a number of relevant economic attributes (Table 1). In terms of population size, population size ranges from a low of 2000 for Niue to 4.5 million for Papua New Guinea. Per capita GDP ranges from US\$594 for Kiribati to US\$6,448 for Palau. Life expectancy amongst the fourteen countries varies from a low of 54.5 years in Nauru to 73 years in Fiji; similarly, aid flows range from US $\$ 4,814$ per capita in Palau or around 75 per cent of per capita GDP to US\$46 per capita in Fiji or around 2 per cent of GDP.

The policy regimes differ just as much. Fiji made an about-turn from an import-led industrialisation to tax free zones in 1987; Papua New Guinea switched from a fixed to floating exchange rates in 1994; and Vanuatu is currently in the process of fiscal decentralisation. The choice of exchange rates that provide fiscal discipline and shield the economy from speculative attacks has been a subject of much discussion following the East Asian financial crisis of 1997. Again, the Pacific island countries provide the entire menu of exchange rate regimes; while Kiribati and Nauru use the Australian dollar, Federated States of Micronesia and Marshall Islands use the US dollar, Fiji and Solomon Islands have their own currency pegged to a basket comprising currencies of their trading partners, and Papua New Guinea has a floating kina. This experience of exchange rate regimes and their impact on the macroeconomy has relevance to the Pacific island countries as much as to the rest of the world.

This paper draws on three lessons from the recent experiences of the island nations of the South Pacific that have relevance to current policymaking in the individual countries. First, property rights are essential to induce investment that, in turn, is necessary for growth. Second, public sector participation has to be limited to regulation and the funding of public services with minimal active participation of the state in commerce. Third, institutions of civil society have to be created, cultivated and protected to provide the environment essential for competition and entrepreneurial activity that in turn delivers quality growth (Rodrik 1999). Particular attention has to be paid to ensuring that an independent, effective, and credible judiciary is maintained at all times. Achieving the last is particularly difficult in small societies and where enclave social groupings are common.

\section{Similarities and differences}

The Pacific island countries are different from each other in several respects but not in terms of their poor economic performance. Annual per capita growth in GDP, taken over the 14-year period from 1982 to 1996 for which consistent data from the World Bank are available, has ranged from a maximum of 2 per cent for Papua New Guinea to less than one per cent for Fiji, Samoa, and Vanuatu. Furthermore, the growth rates between years have gyrated wildly, in part because of weather conditions, including natural disasters (such as cyclones), which affect agricultural production. Of late, political problems such as those in Fiji, Papua New Guinea, and Solomon Islands have adversely affected investment, led to out-migration of skilled and professional labour, and reduced tourist arrivals, and in turn lowered aggregate income.

Another common factor has been high fertility rates, ranging from 2.5 births per woman in Palau to 5.4 in Marshall Islands. These comparably high natural increases have translated into rapidly rising populations, particularly of the young. Fiji, Samoa and Tonga have suffered the least on this count due to high emigration. The rapidly rising populations in a sluggish economic environment, including poor employment 
creation, has produced social problems such as rising crime rates and significant pressures on natural resources, land in particular. The resulting competition over resources has led to rising tensions between communities. For example, competition over land between people from the outer islands and the traditional residents on Guadacanal has led to a near civil war in Solomon Islands, with catastrophic consequences for the economy. Similar problems in Fiji have contributed to the overthrow of a constitutionally elected government and are threatening the viability of their large sugar industry.

Fiscal management in several of the Pacific island countries has been less than exemplary. The consistently high budget deficits over the past decade have led to accumulating public sector debt. Solomon Islands is an extreme example where the government is having difficulty paying for basic services including imports of medicine. Corruption and nepotism have been become serious problems, as many recent scandals have shown. In the case of Fiji, some F\$200 million was lost by the state-owned National Bank of Fiji (NBF) in bad loans to a small number of well-connected borrowers; moreover, there is little hope of bringing the culprits to justice. Papua New Guinea public servants are at risk of losing a large part of their contributions to the Public Officers Superannuation Fund due to failed 'extrajudicial' real estate investments by the trustees.

Notwithstanding the various differences between the island states, the stylised facts of the 14 countries within the South Pacific may be represented as follows. These countries have had poor economic performance both in terms of the level and rates of growth of GDP. Most have also experienced high natural increases in their populations, faced diminishing employment opportunities for their residents, witnessed rising crime and other social problems, and seen an increasing trend in corruption and in the abuse of authority by the élite. These developments collectively have translated into a poor state of human development in the region.

Despite the gloomy picture painted above, there are some less noticeable successes as well as wide diversity on some measures between individual countries. Life expectancy and literacy rates are high in several countries including Fiji, Federated States of Micronesia, Samoa and Tonga. While Fiji can boast of having universal access to primary health care and education services, Papua New Guinea lags considerably on delivery of these basic services. Cook Islands, Samoa and Tonga export professionals to New Zealand to such an extent that remittances comprise a significant proportion of their foreign exchange earnings. These contrasts provide lessons both on the models to follow and those to avoid.

Several of the constraints faced by the Pacific island countries to development emanate from their size, isolation and importantly, their policy regime. For example, Nauru, a nation of 2000 individuals, has little scope for realising economies of scale in the provision of services including primary health care and education. Even for the larger countries such as Papua New Guinea, the rough terrain, dispersed islands, and many languages have made economic integration an expensive task. The distance from major markets such as the Americas and Europe raises the costs of commodity trade. Many of the islands have fragile ecosystems and limited natural resources. Much of Micronesia has control over large areas of the ocean but little (productive) land and minimal local capacity to make intensive use of the ocean resources. Little can be done about these geographical facts of life, but when policy settings are also unfavourable to growth, then growth prospects are even more severely penalised. 


\section{Institutions and development}

Both the neoclassical and endogenous growth theories stress the role of technology and innovation in the growth of economies. A new strand in this literature now emphasises the role of institutions in growth. Mancur Olson Jr's (1996) seminal work on New Institutional Economics makes a compelling case in support of the proposition that 'a country's institutions and economic policies are decisive for its economic performance' (1996:19, emphasis added). ${ }^{1}$

Institutions-defined as 'humanly devised constraints that structure human interaction' (North 1996:360)—comprise formal constraints in the form of rules, laws, and constitutions and informal constraints in the form of norms of behaviour, conventions, and codes of conduct. Institutions, together with the effectiveness of their enforcement, provide the basis for interactions between people and determine the costs of transactions. Effective institutions reduce the costs of transformation and exchange thereby promoting economic activity. Their absence, as shown later, deprives the economy of markets that could be critical for development.

According to North (1994), neoclassical theory is an inappropriate tool to analyse and prescribe policies that will induce development at independence of a nation. This is because the theory is concerned with the operation rather than the development of markets. For development, we need to understand the incentive structure embodied in institutions that determine the level of societal investments in human capital and technology that are the prerequisites for output growth. The evolutionary process that takes place over time within a society enables learning to take place and this in turn shapes the way institutions evolve, leading to either a convergence towards the competitively efficient equilibrium or alternatively to a socially sub-optimal outcome of lower output with accompanying economic inefficiency. The alternatives are depicted in Figure 1.

Figure 1 Hysteresis and lock-in

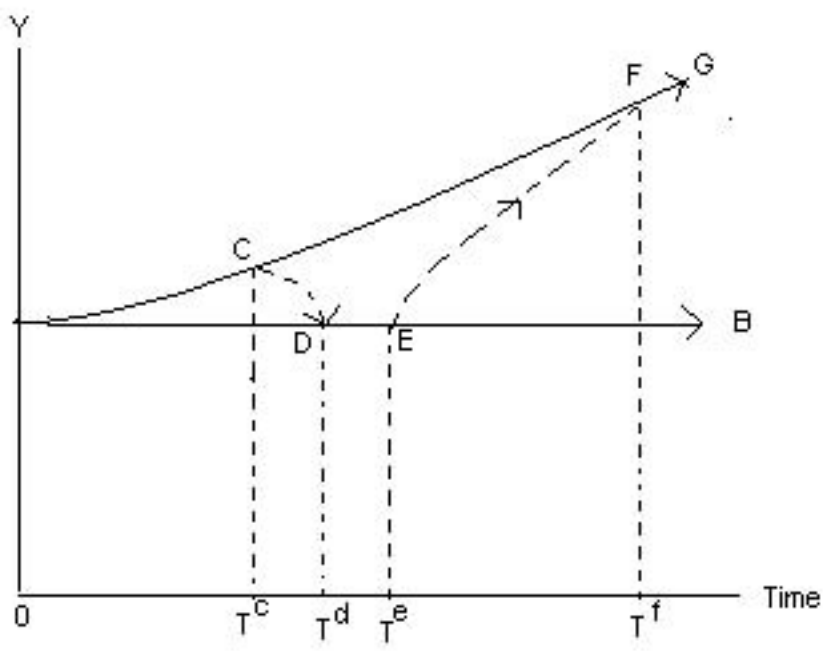


The vertical axis in Figure 1 denotes the level of aggregate output, Y. Time is represented on the horizontal axis; the path labelled G (for good) is the socially preferred path leading to rapid growth in output from the efficient operation of markets. The path labelled B (for bad) is the bad outcome leading to stagnation in output from inefficient use of resources. Path B is unstable (has razor-edge properties) in that a deterioration in economic welfare will lead to a crisis. In contrast, positive growth from $B$ generates sufficient resources to fund institutions for the good of society and will lead to G by enabling the economy to 'shakeoff' socially inefficient behaviour.

The fork at the beginning of time makes the point that initial conditions matter. The jump from $C$ to $D$ may occur as a result of a significant break from established norms such as those arising from a military coup. Once the transition to the new trajectory is made, the path to $D$ is a 'slippery one' and one that takes little time as depicted by the small gap between $\mathrm{T}^{\mathrm{c}}$ and $\mathrm{T}^{\mathrm{d}}$. A transition in the opposite direction can also be made; as shown by the trajectory from $\mathrm{E}$ to $\mathrm{F}$; but this is an 'uphill battle' and one that takes considerably longer. The past experiences of Fiji support these assertions. The trajectories at their initial stages are difficult to distinguish, suggesting that the transition from one path to the other can take place easily at the beginning of the period.

New Institutional Economics (NIE) claims that when it is costly to transact, then institutions have a significant role in determining the level of economic activity. ${ }^{2}$ Furthermore, the tools of economics, according to NIE, are relevant to the analysis of the role of institutions in development (Williamson 2000). Formal features of the institutional environment including the laws, polity, judiciary, and bureaucracy are all critical in the development of a nation state. Contracts are common in everyday life; their credibility and enforceability are critical determinants of the costs of transactions.

According to NIE, it is critical for a nation to establish institutions necessary for development at an early stage. These institutions, when effective, provide the parameters within which economic activity takes place. If development is pathdependent, as Figure 1 suggests, then the prosperity of a nation is determined in its initial stages. Establishing the formal rules of the game and 'getting these rules right' are critically dependent on the initial seeding process. Each society has mechanisms in place that give rise to informal institutions that may subsequently be formalised and over time display significant degrees of inertia; implying a cumulative and gradual process of institution building. These formal and informal institutions have a lasting impact on how a society conducts itself, and provides the reason for hysteresis.

Informal constraints such as sanctions, taboos, customs, traditions, and codes of conduct are often transformed into formal rules in the form of constitutions, laws, property rights, and so on. The chance of survival of these formal constructs is improved dramatically when there is, and perceived to be, a natural transition from the informal to the formal. ${ }^{3}$ In contrast, when there are perceptions of the formal institutions being transplanted from 'a foreign land', the legitimacy of these institutions is severely undermined. Sometimes, vested interests will push such a view in order to weaken institutions.

The formal institutions form the basis for the design of the executive, legislature, judiciary, and bureaucracy. Definition and enforcement of property rights now becomes the key in linking institutions to development. When institutions are formed through a natural process of transition from established norms of society, departure from these established social constraints requires considerable effort. This effort provides the 
basis for a stable society where institutions gradually evolve through a process of incremental change induced by private gains from better-facilitated exchange. Such stability is necessary for long-term investment and sustainable use of natural resources.

The individual's right to property, including personal safety, is critical for longterm investment. Rodrik (1999) suggests that secure and stable property rights were the 'key elements in the rise of the West and the onset of modern economic growth' (1999:3). North claims that 'an essential part of development policy is the creation of polities that will create and enforce property rights' (1994:366). The argument in support of property rights is that

a private-enterprise system cannot function properly unless property rights are created in resources, and, when this is done, someone wishing to use a resource has to pay the owner to obtain it. Chaos disappears and so does the government except that a legal system to define property rights and to arbitrage disputes is, of course, necessary (Coase 1959:12 as quoted in Williamson, 2000:598).

Security of property rights is essential for the development of a capital market with its ensuing benefits in terms of the source of funds for long-term investments, including in research and development activity and infrastructure.

Once property rights are defined and enforced, markets are best able to allocate resources for productive use. When property rights are unclear, incentives for rent-seeking result. Such rent-seeking leads to waste of resources and the dynamics lead to a vicious circle of more rent-seeking and less productive activity as a consequence. The discovery of natural resources that create incentives for the 'owners' of the resource to renege on the contract compounds the problem further. The investor, knowing the problems of timeinconsistency, would engage in socially suboptimal levels of investment when property rights are unclear. The challenge for policymakers in inducing the socially desirable level of investment is to devise contracts that are robust to problems of time inconsistency. Since complete contingent claims contracting is still impossible, contracts are likely to remain incomplete and controversial. Incomplete contracts combined with opportunism leading to strategic behaviour manifests as problems of adverse selection, moral hazard, shirking, and so on. An obvious policy implication from the above is that

parties to a contract who look ahead, recognise potential hazards, work out the contractual ramifications, and fold these into the ex ante contractual agreement obviously enjoy advantages over those who are myopic or take their chances and knock on wood (Williamson 2000:601).

These are important considerations in the case of investment in natural resource exploitation and in infrastructure.

The corruption (defined as abuse of public office for private gain) that is endemic to the Pacific island countries is symptomatic of the failure of institutions in protecting property rights; in this case the rights of the wider community to freedom from embezzlement. Since the incidence of corruption differs widely across countries, it is instructive to consider the reasons for such divergence. The answer from the experiences of the Pacific island countries lies in the presence of the incentives and availability of opportunities for such behaviour. Melanesia provides several insights on the factors responsible for the prevalence of corruption.

Corruption has a debilitating impact on economic growth by penalising economic efficiency, reducing equity in income distribution, and lowering the welfare of the nation as a whole. Corruption reduces the incentives to invest, and hence lowers output and the quality of public infrastructure and services. It diverts public expenditure away from the delivery of basic services to 
construction of 'white elephants' with significant cost to society (Dabla-Norris 2000). Poverty and the incidence of corruption across countries seem to be inextricably linked; corruption prevails in poor countries and vice-versa. Similarly, poor institutional quality is significantly correlated with increased political instability (see Aron 2000 for the correlation matrix for a cross-country sample). Even when the high costs of corruption are well recognised, the affected community is often unable to eradicate it; Papua New Guinea is a good case in point. It is, therefore, instructive to find reasons for persistence of corruption. When corruption is systemic, the likelihood of detection and punishment decreases and incentives are created for further increases in corruption, leading to a vicious circle. Sometimes individuals at the highest levels of government are involved and hence have no incentive to combat this malpractice.

The above suggests the possibility of having multiple equilibria-one with high corruption and low economic activity and the other with low corruption and high economic activity. The persistence of corruption and negative spill over from corruption on growth of output suggests path dependence (see Figure 1). Once corruption becomes ingrained, it is difficult to eradicate and the country is left 'locked-in' in a low growth and high corruption equilibrium. ${ }^{4}$ Corruption thrives in an environment of weak institutions that a poorly resourced government is unable to prop up. Should the institutions be revived - for example through external assistance- then the economy could be steered on to a path leading to the highoutput and low-corruption equilibrium.

\section{Institutions and growth: evidence from the Pacific island countries}

We draw on the experiences of individual Pacific island countries and the group as a whole in suggesting policy lessons for the individual countries. To ensure that the issues raised are covered in sufficient depth, the discussion is confined to the issues raised in the last section. The specific issues covered here include the reasons for the rapid rise in claims for compensation, particularly in Melanesia; the underlying driver of the rising incidences of corruption in public office; the demand for state participation in foreign joint ventures; and the impact of the above on aggregate output and economic growth. The above are the result of weak institutions that have locked-in many of the Pacific island countries in a low growth equilibrium with the associated problems of high and rising crime and unemployment.

\section{Compensation claims-a growth area}

Compensation claims is one of the most rapidly growing businesses in Melanesia. The increase in claims and threats of the same is frustrating resource exploitation in many Pacific island countries and constraining investment in both public and private infrastructure. As an example, the CEO of ELKOM - the statutory authority responsible for the supply of electricity in Papua New Guinea-told the author that land claims were the major impediment to the expansion of the electricity grid in the country. Compensation claims in Fiji following the coup of May 2000 led to the closure of a primary health care centre and threatened the closure of at least one primary school and the only hydro-electricity dam in the country. Expansion of the road network in Papua New Guinea has been constrained not only because land is difficult to acquire but also due to the threat of exorbitant compensation claims ex post construction. Since these foregone public investments would have had a positive spillover on the productivity of private capital, impediments to public investment penalise growth of aggregate output. The institutional framework reward claims for compensation, hence its prevalence. The opaqueness of property 
rights and the difficulty of enforcing contracts create these incentives.

\section{State participation in joint ventures with foreign companies}

Contractual hazards in the form of weak property rights and poor contract enforcement have induced foreign investment in large resource projects only in partnership with the state. For example, the Ok Tedi mining venture was undertaken in partnership with the PNG government. Similarly, many of the larger international hotel chains that operate in Fiji do so in concert with the Chief of the land-owning mataqali. It is not uncommon to see many 'front-office' and 'public relations' positions being given to those with political influence; such departures from the efficient allocation of resources penalise the level of output. Senior politicians are often 'invited' to be a joint-partner, particularly where there are significant conflicts of interest between the public office and the business. These organisational arrangements exist as mechanisms to reduce uncertainty of property rights to resources. The government partners provide some security against the local party reneging on the contract. The outcome is once again at a cost to economic efficiency and the level of aggregate output.

\section{'High-grading' of resources}

Many of the resource-rich Pacific island countries have witnessed resource extraction at unsustainable levels accompanied with 'high-grading'; the latter is defined as where only the best quality resource is exploited. Logging in Solomon Islands over the last decade is perhaps the best example, though similar claims can be made for most of the larger resource projects in the region. This is once again a symptom of weak and insecure property rights to the resource.

Footloose industries, such as the garment sector in Fiji, are another symptom of insecure property rights. In these cases, rents in the form of preferential access to industrial country markets are 'creamed-off' at the maximum rate possible with little regard for future ramifications for such action. Another consequence of timeinconsistent contracts is 'fly-in fly-out' forms of investment; these operations keep sunk costs to a minimum, depriving the region of investments in long-term infrastructure and local capacity building. In the case where the investor is unsure of security of tenure to a resource, 'high-grading' follows as a natural consequence.

Even where property rights are well defined, the inability to enforce such rights has been a problem. For example, most of the commercial banks in Port Moresby refuse to extend credit to the rural sector because land, the largest component of wealth of the rural community, cannot be used as collateral. The CEO of the subsidiary of a commercial bank based in Port Moresby noted that lending to the small coffee sector was risky because debt contracts, particularly on communally owned land, cannot be enforced. The lack of access to credit by the rural subsistence sector due to the inability to securitise assets has impeded the transition from subsistence to commercial agriculture (with its accompanying use of productivityenhancing technology) in all of the Pacific island countries (Chand 2001).

\section{Public hand-outs, once provided, are difficult to withdraw}

Each Member of the PNG Parliament is provided with between one half and one and one half million kina each year in the form of rural development fund (RDF) to spend in their electorates. This discretionary fund was created in 1984 by the then Prime Minister, Sir Michael Somare, with an initial allocation of $\mathrm{K} 45,000$ per MP, but has since grown in size. The abuse of this fund is reported to be widespread. There are reports of the RDF being used to fund bogus community organisations and non-existent (ghost) 
infrastructure. Purging the RDF has proved to be impossible; the current national administration has only succeeded in quarantining the funds to be used for national priorities. This experience demonstrates that handouts, once provided are difficult to be withdraw, as vested interests form to protect and raise the stakes.

\section{Law and order problems and cost of doing business}

Several surveys reveal that law and order problems have been the major impediment to doing business in Papua New Guinea. Using survey data, Duncan and Lawson (1997) argue that the poor and deteriorating law and order problems have constrained the growth of small business in the country. The ensuing low level of investment has limited growth of employment, which in an environment of high growth of the labour force has fed the levels of crime. The rising numbers of unemployed, coupled with poor law enforcement, has trapped the PNG economy in low growth equilibrium (Chand and Levantis 1998). ${ }^{5}$ Low levels of output, deteriorating levels of public revenue and rising levels of crime and corruption have together prevented strengthening of the institutions necessary to contain the growing law and order problem in several Pacific island countries.

When institutions are weak and unable to enforce the rules, deterrence against socially unacceptable behaviour is reduced. The National Bank of Fiji debacle cost the taxpayers in excess of F $\$ 200$ million in bad debts, yet the culprits have not been brought to count. Similarly, the perpetrators of the three coups in Fiji have as yet to be sanctioned, whilst several have benefited handsomely from their acts of treason. The former Prime Minister of Papua New Guinea was shown in TV footage to admitting to be the 'godfather' of criminal gangs in the capital, Port Moresby. This blatant disregard for the rule of law with those responsible seen to be profiteering from such action provides incentives for further criminal activity. The breakdown of institutions such as the legal system raises the costs of transformation and exchange and penalises investment and growth. Moreover, the damage done to institutions of civil society has long-lasting effects and could be responsible for pushing the economy on the $\mathrm{CD}$ trajectory in Figure 1. The rising rates of personal and property crime in several of the Pacific island countries suggest that this may be the case. The erosion of discipline amongst the institutions of legal enforcement is now the greatest threat to the future stability of Fiji and Solomon Islands.

\section{Corruption in Melanesia}

The Pacific island countries as a group have over the recent past seen rising incidences of corruption. The factors that may have helped in this regard include the presence of weak property rights, the abundance of natural resources without effective institutions for managing the expenditure of the resource rents (the reason Melanesia is most prone to corruption), and a policy climate riddled with regulations with discretionary authority given to those in high office. Weak institutions, active state participation in commerce, protection of industry from both foreign and domestic competition, and rising demands for budgetary support to ailing state-owned enterprises feed off each other in maintaining the status quo of stagnant growth and weak institutions. ${ }^{6}$

Four reasons are proposed for the prevalence of corruption amongst the Pacific island countries. First, opaque property rights in the form of communally owned land and fishing zones create the 'problems of the commons'. One such problem is the incentive to free ride on the rights of a kin for personal material gain. The traditional feudal system providing graduated levels of authority is often used to legitimise this abuse, as traditionally the chiefs were the custodians 
of communal interests. The brackish waters of traditional communal ownership of property with the modern capitalist state have provided the opportunity to those vested with trust to 'cash-in' on privileges often bestowed to them via traditional institutions. $^{7}$

Second, the availability of resource rents has rewarded corruption and blatant disregard for contracts in the absence of sanctions that act as a deterrent against such socially sub-optimal behaviour. Realising the time-inconsistency of contracts, investors have raised the risk premium attached to such investment. This has delivered 'footloose capital' and 'high-grading' of resources in the region.

Third, Pacific island societies place heavy demands on their leaders. Traditionally, leaders were expected to provide for and protect their kin. Leadership was passed through inheritance; the eldest son of the chief often acquired the title on the death of his father. These expectations remain for current leaders both in government and the public service, but abiding by the old norms now amounts to nepotism and corruption. Many political aspirants depend on such traditional institutions for support and therefore are obliged to fulfil their traditional dues to the supporters. But, an official making room for his immediate kin to take over his position on departure is nepotism. Helping and protecting the members of the clan, albeit with public resources, is construed as bribery and corruption. Leaders who take advantage of traditional ties to prop them up into office via democratic institutions are left with little option but to abuse their office to maintain the support base.

In traditional societies, taxation and redistribution took place in a transparent manner; savings were hard to make as the fish caught had to be eaten the same day, the pigs in the yard could not be stashed away under the mattress, and so on. Leaders were sanctioned via inheritance and a council of elders; both assisted in the preparation for and in the job. The matai (chief) of the ainga (clan) in Samoa held the position only at the wish of the members; democracy was an integral component in these institutions. These traditions then had a place in ensuring the viability and sustenance of satellite communities. The transition to capitalism is availing opportunities for abuse of traditional institutions for material gain.

Fourth, formation of new institutions has lagged and sometimes been prevented by vested interests. Money can now be hidden in Swiss bank accounts; real estate can be held in all sorts of exotic places; and caviar, chocolate and casino services may now be purchased in secluded resorts away from the view of kin at home. These are not figments of imagination but common practice amongst the élite of the region. Yet, many in the Pacific island countries and often those with vested interests argue for retention of traditional values.

\section{Privatisation and deregulation of the economy}

Some of the Pacific island countries-Fiji and Papua New Guinea in particular-have attempted to deregulate their economies via instituting ambitious privatisation agendas and lowering barriers to international trade. These have not been smooth exercises and success on this front has been elusive. For example, the relaxation of import controls on several basic foods has created strong antiliberalisation lobbies in Fiji. The labour unions have vehemently opposed the privatisation agenda in Papua New Guinea, the support for which is slowly gaining momentum. Vested interests have quickly formed around any privileges extended by the public sector, making it extremely difficult to withdraw such privileges.

The more recent moves to privatise stateowned enterprises in Fiji and Papua New Guinea so as to depoliticise the economy has provided fresh opportunities to divert state 
assets for personal material gain. The motivations for privatisation are genuine in that the change of ownership and management incentives under appropriate competition policies would lead to effective restructuring of the enterprises and raise economic efficiency (see Grossman and Hart 1986). This will also free the public sector from the continuing need to prop up failing state-owned enterprises and in many cases rescuing those that become insolvent. Furthermore, privately-run enterprises allow the public sector to concentrate on regulation with an 'arms length' relationship with the participants in the market; often the state has constrained competition with use of barriers to entry to protect its own enterprises (such as Ilimo Poultry in Papua New Guinea). The translation of the above intentions into practice provides opportunities for 'insider trading' such that public assets at the point of divestiture could be transferred to cronies at a discount. In several cases of corporatisation, the CEOs have been awarded generous contracts, only to be rescinded in the interim with multi-million dollar compensation payouts.

\section{Policy lessons for development}

Initial conditions matter for the development of a nation. It is critical to get the right institutions to begin the process of positive feedback between growth in output and strengthening of institutions, so that the economy is able to move on to the high growth trajectory. Drawing on the experiences of the Pacific island countries, three specific recommendations can be made.

First, institutions will only stand the test of time if they grow out of a process of natural evolution and incremental change from longaccepted norms of the society. The transition must be transparent and perceptions of 'foreign impositions', even if canvassed by vested interests, are to be avoided. Only then will the institutions that form the bedrock of development not be undermined.

Second, the persistence of corruption suggests that the design of policies that minimise opportunities for corruption should be preferred over the design of remedial ex post action. Options worthy of consideration in this regard include an open trade regime, simple rules with minimal discretion given to policymakers, and minimising the extent of public sector activity in commerce. One lesson from the Pacific island countries is that if opportunities for abuse exist, chances are they will be taken advantage of. The experience in Melanesia suggests that corruption is difficult to eradicate once ingrained, hence prevention is the preferred strategy. Transparency in operation of governments, an active media, and a wellpaid and professional public service are a few of the options worthy of detailed consideration.

Third, given the small size of the population and enclave nature of the legal and media professions, it is imperative that there is foreign participation in these sectors. Perhaps donor countries could provide senior professionals for the judiciary, the executive including the office of the auditor general, and the disciplinary forces. In the interests of transparency, the foreign media could be given free access to report in and on the country.

The longer-term challenges for all the Pacific island countries will remain the strengthening of institutions of civil society. Transparency in decision making together with a well-informed electorate would go a long way in instilling better governance in the country. Allowing foreign media to operate freely in the country together with improvements in information-disseminating facilities, such as access to radio services, would go a long way in helping good governance. 


\section{Conclusions}

Economies tend to display path dependence; ie cross-country data show that growth or stagnation in individual economies tends to persist over time. Several of the Pacific island countries support this proposition in that they have been stagnant for much of the last two decades. Insights into the reasons for such persistence could be of value in the design of policies for rekindling of growth. This paper has argued that initial conditions, in the form of institutions adopted at the birth of a nation, matter for the subsequent level and rate of development.

The literature on New Institutional Economics argues that economic performance is governed by the structure of incentives. These incentives, in the form of economic policies and institutions, are contained within the national borders of a country. It would, therefore, be opportune for the individual Pacific island countries to draw on the experiences of the others in collating the 'right' set of institutions and policies. Such an exercise could indeed be a major contribution, but mistakes in compiling this list could be equally disastrous if the cumulative nature of institutional growth and self-reinforcing mechanisms in the process are to be believed.

The transition from informal to the formal institutions, the management of perceptions in this transition, and the enforcement characteristics define the bounds of economic performance. The longevity and legitimacy of formal institutions is dependent on the nature of transition from the traditional norms to the formal institutions. These lessons have direct relevance to the resolution of land tenure problems and bringing the political impasse to a close in several of the Pacific island countries.

Turning an economy around is difficult once it is set on a path of stagnation due to the lock-in effects inherent in political and economic processes. The experiences from the island states of the South Pacific offer several examples. The challenge is to learn from mistakes of the past; a non-trivial task given the extent of repetition of mistakes to date.

There is an obvious need to create and enforce property rights. Such rights include those to personal safety, security to property, and to information that is of public interest. A free and active media together with an independent judiciary are necessary, albeit not sufficient, steps in the right direction. Given the small size of communities and the enclave nature of the legal and media professions, foreign participation is crucial if the independence and credibility of these two institutions is to be protected. Aid may be used in the immediate term to fill positions that require independence. Several of the Pacific island countries have relied on judges, public prosecutors, central bankers, and auditor generals from abroad to build local expertise and provide short-term credence to these offices; a model that could be followed elsewhere. The long-term solution is to build local capacity where the professionalism of office bearers and ethics of the job, together with an open peer review process, should ensure credible delivery of the services that are critical for development.

The challenge for now is to establish an appropriate policy regime and within the limited budget to induce investment and economic growth. Institutions have to be put in place now to ensure the resulting growth translates into the sharing of benefits by the wider community.

\section{Notes}

1 See Williamson (2000) and Aron (2000) for recent surveys on New Institutional Economics and economic growth.

2 The neoclassical result of efficient markets materialises in a world with perfect 
competition, full information, and costless transactions; departure from these ideals are greatest at an early stage of development.

3 Lal claims greater hysteresis in cosmological as against material beliefs of the people and that rulers, as a matter of historical fact, seek rents 'to feather their own nests' (1999:8).

4 The relationship between corruption and the wider economy is analogous to that between a parasite and the host; for the parasite to live, the host has to remain alive but a thriving host is also a threat since it can shake the parasite off.

5 Chand and Levantis calculate that the probability of sanction for crimes of larceny is 'barely one per cent' (1998:38).

6 There are suggestions that corruption is institutionalised in the region and supported by kleptocratic states. For example, Garnaut (2000) points out that by 1999, Papua New Guinea had become a kleptocratic state.

7 Ratuva (2000) provides an example in the form of Fijian Holdings Limited where those in trust have abused communal ties via traditional institutions for personal material gain. This is one of several examples from the Pacific island countries.

\section{References}

Aron, J., 2000. 'Growth and Institutions: a review of the evidence', The World Bank Research Observer, 15(1):99-135.

Chand, S., 2001. 'Financial sector development and economic growth in Pacific islands countries', paper presented at the conference Financial Sector Stability and Development: The Case of the Pacific Island Countries, sponsored by the International Monetary Fund and the Pacific Financial Technical Assistance Centre, Apia.

Chand, S. and Levantis, T., 1998. 'The nexus between crime and productivity in Papua New Guinea', in S. Chand (ed.), Productivity Performance in the South Pacific, Asia Pacific Press, The Australian National University, Canberra.
Dabla-Noris, E., 2000. 'Corruption', IMF Research Bulletin, 1(3):5-7

Duncan, R. and Lawson, T., 1997. Cost Structures in Papua New Guinea, Discussion Paper Number 69, Institute of National Affairs, Port Moresby.

Garnaut, R., 2000. 'The first 25 years of searching for development', Pacific Economic Bulletin, 15(2) Supp.:29-36.

Grossman, S. and Hart, O., 1986. 'The costs and benefits of ownership: a theory of vertical and lateral integration', Journal of Political Economy, 94(4):691-719.

Lal, D., 1999. 'Culture, democracy, and development: the impact of formal and informal institutions on development', IMF Conference on Second Generation Reforms, Washington, DC.

North, D., 1991. 'Institutions', Journal of Economic Perspectives, 5(1):355-67.

_-1994. 'Economic performance through time', American Economic Review, 84(3):359-68.

Olson, M. Jr, 1996. 'Big bills left on the sidewalk: why some nations are rich, and others are poor', Journal of Economic Perspectives, 10(2):3-24.

Ratuva, S., 2000. 'Addressing inequality? Economic affirmative action and communal capitalism in post-coup Fiji', in H. Akram-Lodhi (ed.), Confronting Fiji Futures, Asia Pacific Press, The Australian National University, Canberra.

Robson, A.R.W., 2000. Costly enforcement of property rights and the Coase Theorem, Economics Department, University of California, Irvine (unpublished).

Rodrik, D., 1999. 'Institutions for high quality growth: what they are and how to acquire them', presented at the IMF Conference on Second Generation Reforms, Washington, DC.

Williamson, O.E., 2000. 'The New Institutional Economics: taking stock, looking ahead', Journal of Economic Literature, 38:595-613. 